\title{
Developing communication skills: a task-based learning approach
}

\author{
Célia Elisa Alves de Magalhães \\ Pontifícia Universidade Católica do Rio de Janeiro
}

\begin{abstract}
Resumo
O objetivo deste trabalho é compartilhar uma experiência de ensino de inglês como língua estrangeira segundo a metodologia de nome Aprendizagem Baseada em Tarefas, em uma aula voltada para o desenvolvimento da fluência de alunos em nível avançado de proficiência na língua inglesa. A Aprendizagem Baseada em Tarefas configura-se como um meio de aprender a língua por intermédio de tarefas negociadas pelos alunos com o auxílio do professor, que é visto como um facilitador de oportunidades de aprendizado na aula. A experiência descrita neste trabalho pode ser considerada por professores que visam a mudança de uma abordagem de ensino centrada no professor para uma abordagem centrada no aprendiz, na qual os alunos desempenham um papel mais ativo e independente.

Palavras-chave: tarefa, Ensino de Língua Baseado em Tarefas, Aprendizagem Baseada em Tarefas, ensino de inglês.
\end{abstract}

\begin{abstract}
The objective of this paper is to share an experience of teaching English as a foreign language according to the Task-Based Approach in a fluency-oriented lesson for advanced learners of English. The Task-Based Approach is a means of learning the language by doing tasks negotiated by learners with the help of the teacher, who is viewed as a facilitator of learning opportunities in class. The experience described in this paper may be considered by teachers who aim to move from a teacher-centered approach to a learner-centered approach, in which students play a more active and independent role.

Key words: task, Task-Based Language Teaching, Task-Based Approach, English teaching.
\end{abstract}

\section{INTRODUCTION}

Having a routine or an established teaching pattern provides us with a safe framework, besides saving us precious thinking time. Nevertheless, as our awareness of other methodological possibilities develops, we start to look for alternative ways of teaching. Ideally, when seeking to adopt alternative teaching strategies, teachers should try to resort to a methodology that will suit learners' objectives, likes and needs, without disregarding the target educational aims and context. Obviously, such a teaching attitude might mean taking into account the possibility of not following rigid methods or teaching routines that rely solely on traditional textbooks. 
Unfortunately, we are sometimes guided by established beliefs and practices that hinder us from experimenting with different methods or aspects from different approaches. As an experienced teacher of English as a foreign language (EFL), I believe that the use of different teaching possibilities can spark off pedagogical experiences that might question beliefs about the teaching-learning process for the benefit of learners. Therefore, I argue in favor of approaches and techniques, which are less often adopted by teachers.

In this paper, I would like to share a teaching experience I had, some time ago, with a method called Task-based learning (TBL) or Task-based approach (TBA). My main objective in using this method ${ }^{1}$ was to check whether it could provide opportunities for advanced learners of EFL to improve their lexis and speaking skills when taking part in group discussions, especially as regards the use of language for interaction. To this end, I planned a lesson based on TBA and observed whether students' language production and speaking skills would develop as the lesson

progressed, since they would have to draw on their own linguistic resources and knowledge of the world to perform the assigned task.

In what follows, I shall present a number of conceptual constructs underpinning this method, before moving on to present the teaching context and analysis of the outcomes of my experiential teaching.

\section{THE TASK-BASED APPROACH}

Task-based language learning (TBLL) is a method which focuses on the learning of languages by means of tasks performed by learners (STANLEY, 2003; WILLIS, 2000). According to Nunan (1989, p. 10), a task is "A piece of classroom work which involves learners in comprehending, manipulating, producing or interacting in the target language while their attention is principally focused on meaning rather than form". Rooney (2000) explains that in TBLL a task provides comprehensible input and promotes communicative interaction among learners using the target language. The amount of comprehensible input and interaction may promote acquisition, which is the major claim of the input hypothesis of Krashen (1985).

TBA evolved from the Communicative Approach (CA) in the eighties as an alternative to the limitations of the presentation-practice-production model (PPP), the three stages into which a 
CA lesson is often divided (RICHARDS; RODGERS, 1986). In PPP, language items are presented in texts or in dialogues, for example, and practiced in a controlled way. Subsequently, learners are given a communication task such as a role play and are expected to produce the target language. In TBA, learners, in pairs or groups, rehearse a conversation or a monologue before holding that conversation or monologue again in front of an audience. According to Stanley (2003), the opportunity to practice the target language in a safer situation in which learners will be familiar with problems that might occur is a key means to promote learning. Willis (2000) suggests that by focusing on meanings in contexts and then examining the wordings, learners realize the meanings. TBA also incorporates features from the Lexical Approach (LEWIS, 1993) regarding the use of texts for learners to "notice" chunks of language. In conclusion, in TBA, we can, to a certain extent, expect independent learning.

Willis and Willis (1996) divide TBA into three main phases, namely, the pre-task, the task cycle, and the language focus. In brief, the pre-task provides learners with useful exposure to recall relevant grammatical and lexical items and to recognize new ones. The task cycle emphasizes the spontaneous, exploratory talk and confidence-building that occurs within small groups. Finally, the language focus aims to explore and systematize language; raise awareness of aspects of syntax, collocation, and lexis; as well as clarify concepts.

\section{THE TEACHING CONTEXT}

The language school where my experiential lesson was implemented is a private institution located in the state of Rio de Janeiro. The institution teaches English as a foreign language to children, teenagers and adults on weekdays and on Saturdays. Classes are offered once or twice a week, on weekdays and on Saturdays. Teachers follow the Communicative Approach and use course books adopted by the institution as well as computer-based activities in their lessons.

A group of eighteen Brazilians aged between 16 and 68 years old participated in the TBA lesson I taught. The youngest student was about to finish secondary school; the eldest had a university degree and worked in various fields. They had all been studying English for an average

\footnotetext{
1 In this paper, I use the terms method and approach interchangeably. For more information on the differences, see MAGALHÃES, C. E. A. de. Diferentes metodologias no ensino de inglês como língua estrangeira: Reflexões por uma prática significativa. Revista Escrita, no. 15, p. 1-11, 2012.
} 
of five years and they intended to learn the language for a number of reasons, mostly for career purposes. They had two English classes of one hour and thirty minutes each on Saturday mornings, on a regular basis. Nonetheless, the target lesson aimed to last sixty minutes, which is closer to the standard amount of time allotted to an English lesson in language schools in Rio de Janeiro.

\section{IMPLEMENTATION OF THE LESSON AND THE ANALYSIS CRITERIA}

Before implementing the lesson, I carried out a needs analysis session. The needs analysis showed that most students in this group needed improvement mainly in listening skills and in lexis (graphs 1 and 2, Appendix A). As for speaking skills, learners felt that the two most difficult aspects to be developed were the following: the ability to use appropriate vocabulary and the ability to use communicative skills (graph 3, Appendix A). Therefore, in this particular TBA lesson, I decided to focus on functional language and develop speaking skills during fluencyoriented activities.

In my classes as well as in those of my colleagues', I have observed that in fluencyoriented activities, Brazilian students' discussions tend to be full of overlapping talk. Students tend to simply raise their voices in order to keep on or start talking, rather than politely interrupt speakers in order to take the next turn in the interaction. Additionally, while extroverted students may try to monopolize discussions, introverted students might remain silent. In an attempt to promote equal student participation in the group discussion, I decided to assign the role of a "chairperson" to a student in each group. The chairperson is responsible for ensuring that everyone will speak. He / She may also be the one to report the group's opinions back to class.

The lesson plan with instructions for the lesson implementation is in the Appendices section. The analysis of the lesson is based on my own observation and on the feedback from students, who answered a questionnaire (Appendix B). The aspects considered in my observation of the lesson implementation are listed below.

- Were students actively engaged in the tasks? Did they show any signs of boredom? Did they seem to be willing to cooperate and to help peers? Did the "Chairperson" ensure that everyone would have a turn and speak?

- Were students able to handle communication? Did they use the target language for interaction (See Appendix D for examples of the language expected for the 
interaction)? Did they respect turn-taking? Did they maintain a natural flow of language? Were they able to use suitable linguistic resources to express complex ideas and concepts? Did they produce discourse that was coherent and easy to follow? Did students' level of accuracy and fluency improve as the task evolved?

- Did students like the topic of the lesson? Did everyone have the opportunity to participate and express ideas? Was the "Chairperson" helpful? Did the lesson help improve communication skills? Did the lesson help students learn/review vocabulary related to the target topic (education)? What did students like about the lesson? What did they dislike? Would they like to have other classes like this?

\section{THE OUTCOMES OF THE TBA LESSON}

In general, learners were actively engaged in the tasks, apart from one student who showed signs of boredom. Despite not using the language of interaction all the time, students handled communication successfully. They reported having difficulty to remember to use this language, which could be due to cultural differences between the etiquette of social interaction in England and in Brazil. Nevertheless, turn-taking was respected.

Although students produced coherent discourse, they did not always use appropriate linguistic resources to express complex ideas. However, I could not observe whether all the students' level of accuracy and fluency really improved as the task evolved, but I noticed that a natural flow of language was maintained.

Students liked the topic and they all stated that everyone had had the opportunity to speak. Nonetheless, two students reported that not everyone in the group had participated. Despite the fact that the majority considered the "Chairperson" helpful, a female student who was the "Chairman" for her group reported having difficulty to monitor classmates' participation and to express her own ideas at the same time. Most students felt the lesson helped them to improve their communication skills and vocabulary. All the students would appreciate having other classes like this and most of them reported that they had particularly enjoyed the speaking opportunities and the group interaction. Three students mentioned the "Chairman" as a positive feature. Apparently, there was nothing that they disliked about the class.

Considering my teaching context, I believe TBA is valuable for a number of reasons. Firstly, as a learner-centered approach, TBA relies on the learners' knowledge - and advanced 
learners have substantial language knowledge. Consequently, learners are required to recall and use their own linguistic resources. Secondly, learning this way can be a collaborative enterprise, in which a great deal of negotiation between the teacher and learners occurs. And collaboration might foster motivation. Thirdly, TBA is particularly relevant because language is used for purposeful communication and this method provides room for communicative interaction. Finally, the planning stage encourages learners to consider appropriateness and accuracy of language form, rather than the production of a single form.

All in all, I particularly enjoyed the experience of trying out a different method and I think there is room for more TBA lessons in my teaching, though not on a regular basis due to a number of drawbacks. Firstly, learners would need more knowledge of their own roles and the teacher's roles in the TBA approach to profit more from this method of instruction, which would be timeconsuming. Secondly, the course materials would have to be adapted to suit both the method and learners' needs. This adaptation might not be possible due to syllabus constraints. Finally, TBA lessons should not be offered regularly because there is an aspect of unpredictability as to the language systems to be covered in them, and advanced students have a wide range of linguistic items to study. In brief, teachers cannot be certain as to whether all the target items to be covered in advanced lessons will be dealt with in TBA classes.

Regarding my own professional development, I will have to challenge my beliefs about language learning, if I am to use TBA again. For example, allowing students to produce language freely without intervening is an aspect I will have to work on. Although I often monitor from a distance, recording examples of learners' language discreetly, I tend to provide students with new lexis before group work activities and to correct mistakes in form as soon as students finish a task. Depending on the task objective, I also use on-the-spot correction. In contrast, TBA requires teachers to refrain from such procedures and to lead students to language analysis only at the end of the lesson. That is why this TBA lesson was an opportunity for reflection and improvement on my part as I had to withdraw from a controlling position. Another feature of TBA lessons that I realized demanded close attention was the management of time. Because the lesson is split into a number of main stages and sub-stages, each move and activity has to be carefully timed so as to equally cater for all the phases in the lesson. 


\section{CONCLUSION}

The TBA lesson engaged learners in purposeful communication. In addition, it offered a change from the grammar practice routines that many learners are used to. It also encouraged learners to experiment with whatever English they could recall and to take active control of their own learning. Certainly, this lesson catered for a learner-centered teaching environment by fostering the co-construction of knowledge and learner autonomy.

Yet, TBA teaching may have its limitations. For example, it was difficult to measure learners' improvement as the lesson progressed. Although, the "Chairman" helped monitor the use of the language for interaction, it was difficult to assure learners would leave the classroom with other linguistic gains. Furthermore, I felt uncomfortable because I could not either teach new words or correct language form during the pre-task phase.

In conclusion, I felt that a TBL approach might be useful to teach lessons in advanced learners' classes, but not on a regular basis because advanced students also need systematized lessons to assure they will produce appropriate lexis and grammar structures. But these conclusions just express my own opinions and beliefs, which may change depending on the different teaching contexts I am exposed to.

\section{REFERENCES}

KRASHEN, S. The input hypothesis: issues and implications. London: Longman, 1985.

LEWIS, M. The lexical approach. Hove: Language Teaching Publications, 1993.

NUNAN, D. Designing tasks for the communicative classroom. Cambridge: Cambridge University Press, 1989.

ROONEY, K. Redesigning non-task-based materials to fit a task-based framework. The Interney TESL Journal, 6(12), 2000. Disponível em http://iteslj.org/Techniques/Rooney-TaskBased.html

STANLEY, K. A question of definitions: an investigation through the definitions and practices of communicative and task-based approaches. TESL-EJ Forum, 7(3), 2003. Disponível em http://www.tesl-ej.org/wordpress/issues/volume7/ej27/

WILLIS, J.; WILLIS, D. Challenge and change in language teaching. Oxford: Heinemann ELT, 1996. 
WILLIS, J. Holistic Approach to task-based course design, JALT Publications, 2000. Disponível em http://www.jalt publications.org/tlt/articles/2000/02/willis

RICHARDS, J. C.; RODGERS. Approaches and methods in language teaching. Cambridge: Cambridge University Press, 1986.

\section{A AUTORA}

Célia Elisa Alves de Magalhães é Doutoranda e Mestre em Estudos da Linguagem pela Pontifícia Universidade Católica do Rio de Janeiro, e Especialista em Língua Inglesa pela Universidade do Estado do Rio de Janeiro. Trabalhou como professora de inglês e como coordenadora em cursos de idiomas. Atualmente ministra aulas de língua inglesa na rede privada de ensino do Rio de Janeiro.

E-mail: elisa.celiamagalhaes@gmail.com

\section{APPENDIX A: NEEDS ANALYSIS RESULTS}

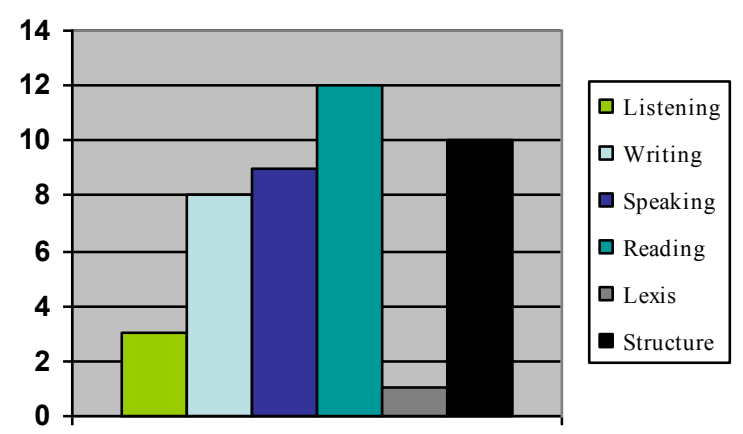

Graph 1: What are your strengths in English?

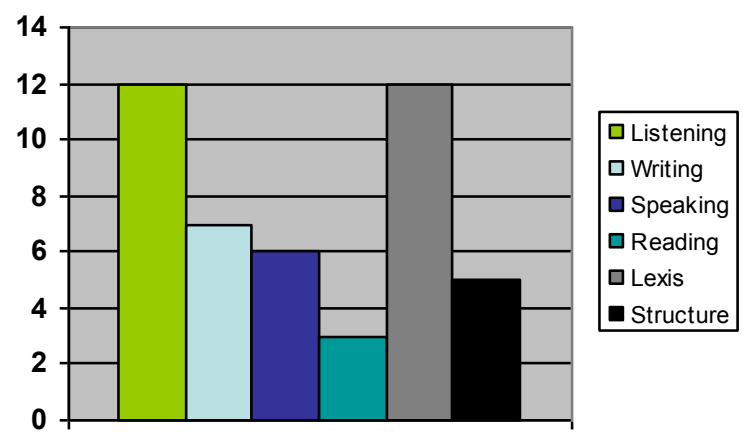

Graph 2: What are your weaknesses in English? 


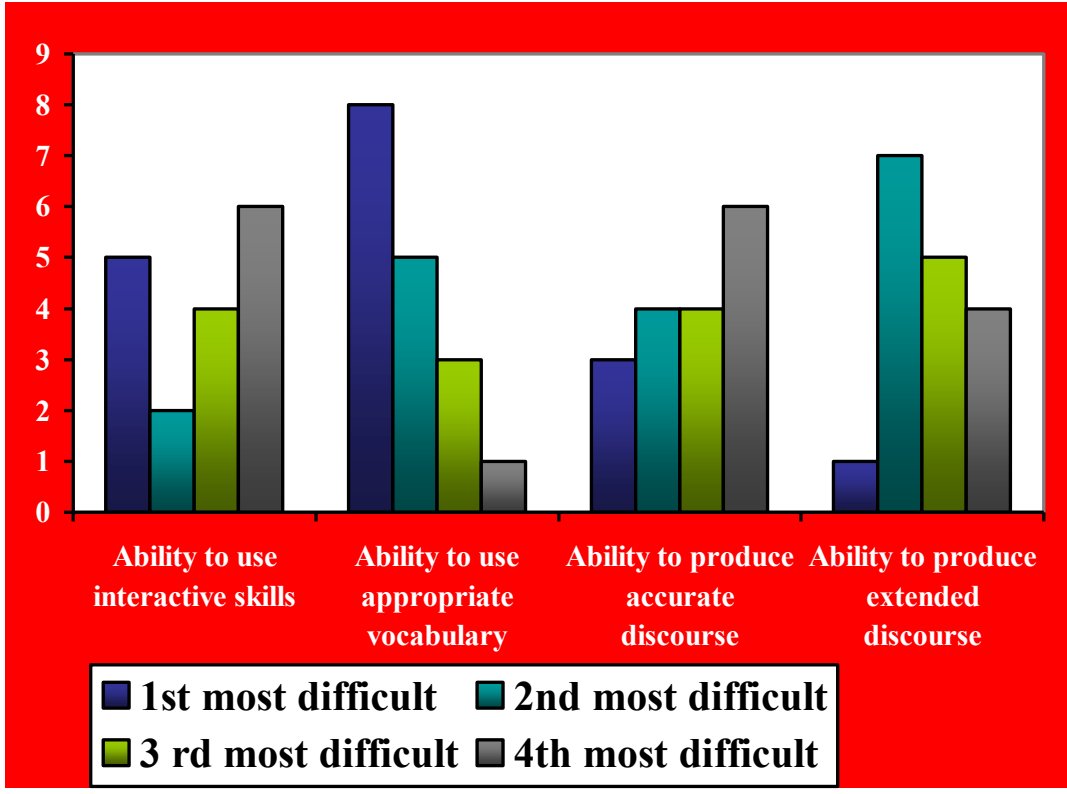

Graph 3: How would you rate speaking abilities, from the most to the least difficult to develop?

APPENDIX B: LESSON PLAN

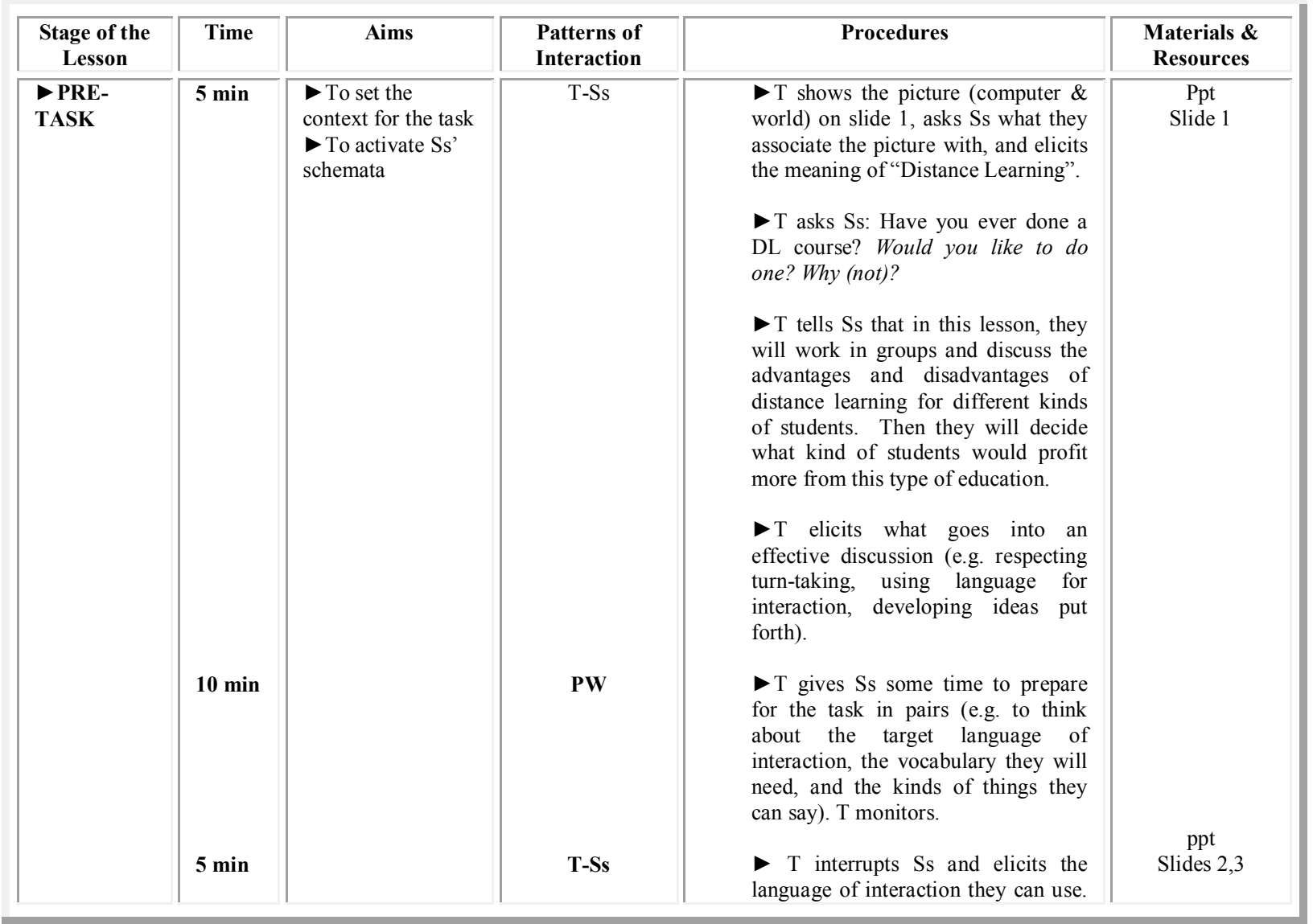




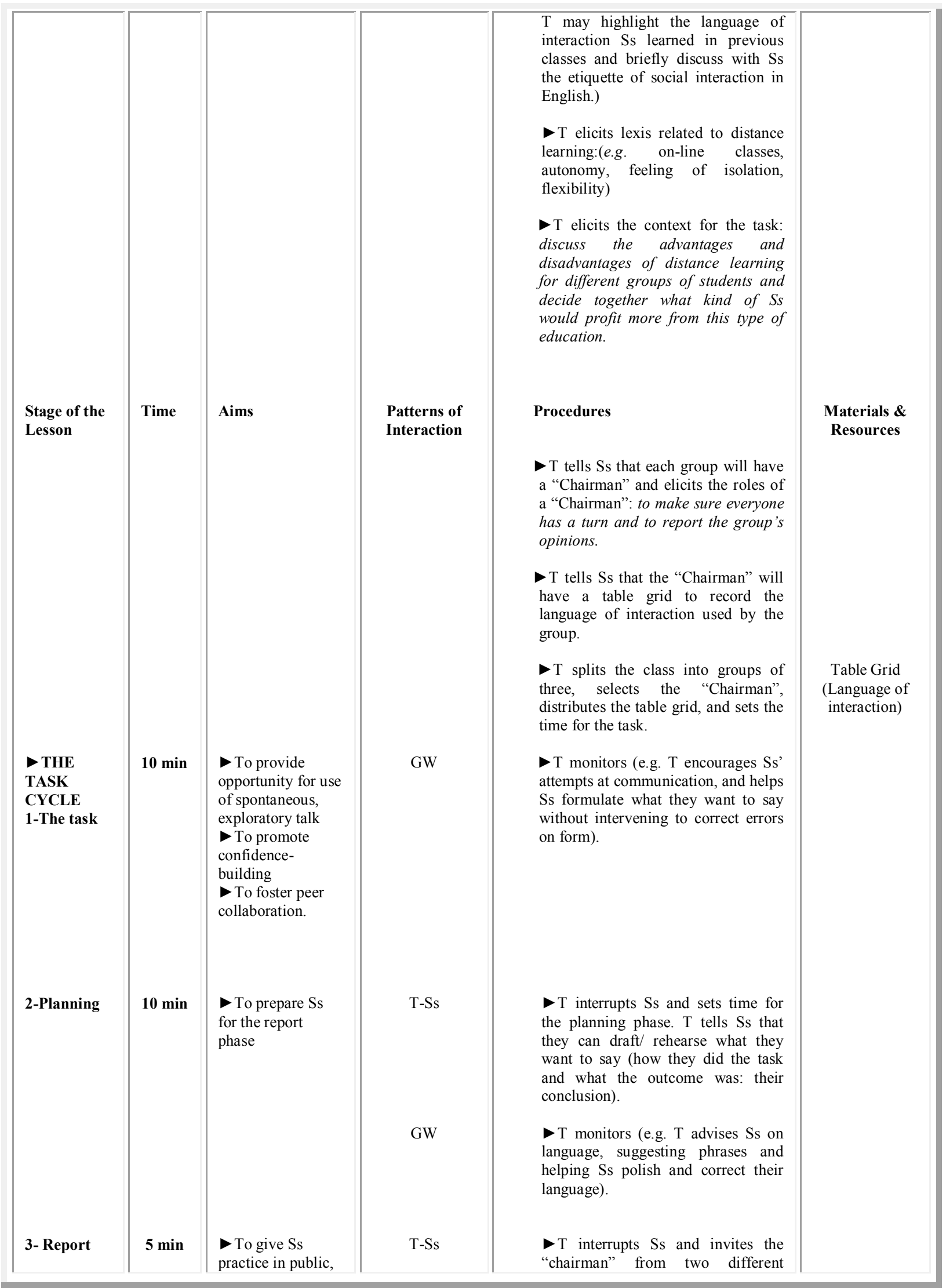




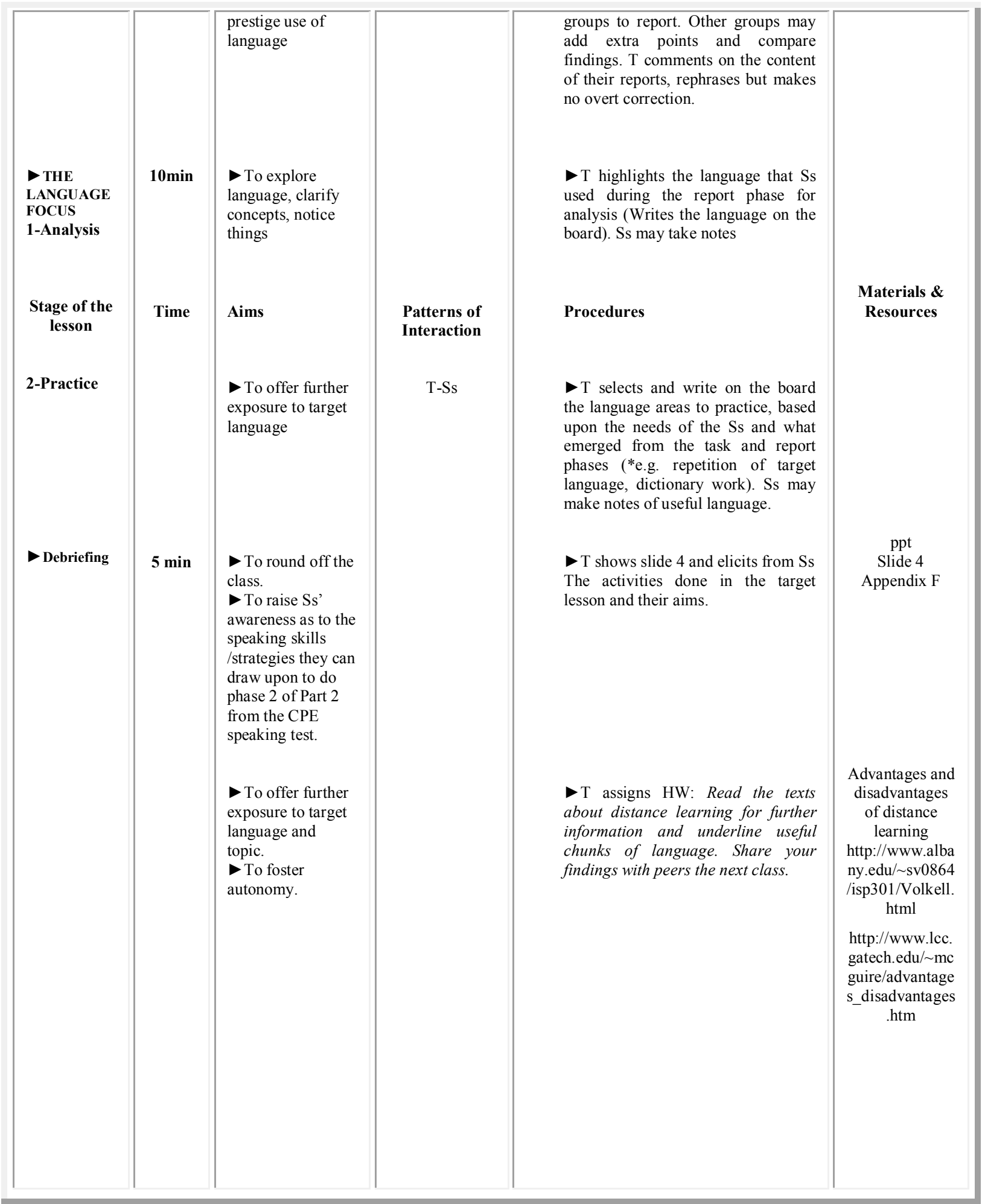

$\mathrm{T}=$ Teacher, $\mathrm{S}=$ Student, $\mathrm{PW}=$ Pair Work; GW = Group Work; ppt = Power Point Presentation, HW = Homework Note: Due to the scope of this paper, the ppt and other materials in the lesson plan are not in the Appendices. 


\section{APPENDIX C: LEARNERS' QUESTIONNAIRE FOR FEEDBACK ON THE LESSON}

\begin{tabular}{|l|l|}
\hline TEACHER \& TEACHING & Was the topic of the lesson interesting? \\
\hline $\begin{array}{l}\text { Did you have the opportunity to } \\
\text { participate and express your opinions? }\end{array}$ \\
\hline $\begin{array}{l}\text { Did everyone in the group participate in } \\
\text { the tasks? }\end{array}$ \\
\hline $\begin{array}{l}\text { Was the "Chairperson" helpful (by } \\
\text { noting down language of interaction } \\
\text { produced, by ensuring that everyone had } \\
\text { a turn)? }\end{array}$ \\
\hline $\begin{array}{l}\text { Do you think this lesson helped improve } \\
\text { your communication skills (by reviewing } \\
\text { speaking strategies and functional } \\
\text { language for interaction, and giving } \\
\text { opportunity for group work)? }\end{array}$
\end{tabular}

What did you like about this class?

What did you dislike about this class?

Would you like to have other classes like this?

Other comments/ suggestions:

\section{APPENDIX D: TARGET LANGUAGE ITEMS}

Expressing opinion: I believe; If you ask me...; Wouldn't you say that...?; As I see it...

Agreeing: I completely agree; I couldn't agree more; That's a good point.

Disagreeing: Maybe, but don't you think that...; Well, you have a point there but...

Interrupting: Sorry to interrupt, but...

Emphasizing the truth of something: As a matter of fact...; Actually...; Indeed...

Expressing doubt: I'm not entirely convinced..., I have my doubts.

Expressing a drawback or disadvantage: The only real flaw...;The greatest advantage of... is...; A major disadvantage of... is... 
Acknowledging that a point has credibility: It's widely accepted that...; Most people would agree that...; There is a consensus of opinion that...; It's very usual to hear that...

Referring back to something has mentioned previously: As I said before...; As I mentioned previously...

- Starting to give opinions on a subject: I'd like to start off by saying...; I'd like to make it clear from the start...; Let me begin by saying... 